\title{
"The Safeness of Standing Alone": Alfred Stieglitz, Camera Work, and the Organizational Roots of the American Avant-Garde
}

\author{
J.M. Mancini
}

The Secessionist Idea is neither the servant nor the product of a medium. It is a spirit. Let us say it is the Spirit of the Lamp; the old and discolored, the too frequently despised, the too often discarded lamp of honesty; honesty of aim, honesty of self-expression, honesty of revolt against the autocracy of convention. The Photo-Secession is not the keeper of this Lamp, but lights it when it may[.]

("The Editors' Page," Camera Work 18 (April 1907), 37)

The Secessionists care little for popular approval, insisting upon works, not faith, and believing that their share having been done in producing the work, the public must now do the rest. A few friends, and these of understanding mind, a few true appreciators, this is all they expect and all they desire. (Hartmann 1904, 47) 


\section{Stieglitz, "Seer" and Organizer}

By many accounts, modern art arrived on American shores sometime after 1905, due in large part to the efforts of photographer Alfred Stieglitz. If the 1913 Armory Show (and its peevish public reception) marked modernism's official American coming-out party, Stieglitz's intimate exhibits of works by Rodin, Matisse, and Picasso between 1905 and 1912 served as the new art's formal letter of introduction to a smaller and more powerful viewershıp (Dijkstra 1969, Homer 1977, Zilczer 1985). Not merely an importer but an artist in his own right, Stieglitz has also been widely credited with transforming photography into one of the primary venues for modernist experimentation in the United States (Orvell 1989; Haines 1982), ${ }^{1}$ a transformation which parallelled Frank Lloyd Wright's drive in architecture towards a vernacular American modernism (Crunden 1982, 133-62). Although scholars disagree on the degree to which Stieglitz himself initiated American photography's turn away from the academic, pictorialist style of the turn of the century towards the hard-edged, geometric productions of the following decades (Arrowsmith and West 1992; Bunnell 1993, 1-38; Homer 1983; Peterson 1993; Petruck 1981; Watson 1991), few have denied Stieglitz and the photographic school he engendered a central place in the pantheon of American visual modernism. ${ }^{2}$

Yet, Stieglitz's talent as an artist and connoisseur of the new only partially explains his success within the art world, both occluding his relationship to his predecessors and prohibiting a more nuanced understanding of photographic modernism's emergence and rise to preeminence in the United States. ${ }^{3}$ Stieglitz's proficiency as an art-world organizer, as much as the freshness of his vision, transformed the face of photographic production in America, and provided a model for artists working in other media, as well. ${ }^{4}$ As both a preserver of the heavily organizational approach to artistic production championed by his Gilded Age predecessors, and an innovator on those forms, Stieglitz gave new shape to American understandings of artistic creation. ${ }^{5}$ Like the Gilded Age institution builders who had sought to promote the development of art in America through the establishment of museums, schools, and criticism, Stieglitz made a place for photography among the fine arts both by developing institutions devoted to its advance- 
ment and through constant negotiation for its acceptance among the al ready established structures of the art world (Keller 1984). ${ }^{6}$

Stieglitz reimagined the nature and function of criticism in significant ways. If he utilized time-tested institutional means to build a place for artistic photography in a literal sense, he used criticism to achieve a more specific but more metaphorical construction, building his circle into an avant-garde, presumably independent of art-world ties, and constructing their works as the inevitable, natural next step in the development of artistic photography. By billing the promotion of a particular set of producers and productions as a crusade for the promotion of artistic photography per se, Stieglitz closed off alternative definitions of artistic photography and represented his associates as the only and self-evident future of art (Trachtenberg 1989, ch. 4). ${ }^{7}$ Through this refashioning of criticism, and through the construction of a vertically integrated organizational structure that mirrored contemporary moves towards consolidation in business and industry, Stieglitz secured a lasting place in the American cultural imagination not only for modernist photography, ${ }^{8}$ but for the avant-garde ${ }^{9}$ itself.

\section{Vertical Integration}

Stieglitz's art-world empire consisted of three central organizations: the Photo-Secession, founded in 1902, Camera Work, a journal which ran from 1903 to 1917, and the "Little Galleries" at 291 Fifth Avenue in New York, which began operation in 1905 (Naef 1978, 116-53). Self-consciously modelled after the various European splinter groups from which it took its name, the Photo-Secession joined photographers and sympathizers in an association devoted to the acceptance of photography as a valid artistic medium. Not only a convenient gate-keeping device, whereby membership readily distinguished insiders from outsiders, the association also helped to shape the boundaries of a united front for entry into competitions, exhibitions, and the like, undergirding aesthetic sympathy with the bond of formal association. Membership within the Photo-Secession, like membership within the Society of American Artists, the Ten, and the range of other formal and informal associations that artists formed throughout the nineteenth century, provided artists not only with sheltered opportunities for 
exhibition within the fold, but offered solidarity and common cause to those with grievances against the hanging committees that determined the composition of most large, public exhibitions.

As the public face of the Photo-Secession, the Little Galleries ("291") served as the starting point from which Stieglitz could develop and control a context of display amenable to Secessionist needs, providing a seemingly "independent" space in which members' works could be displayed without outside "interference." As a site for the presentation of works by artists in nonphotographic fields, it served as a forge in which to fashion Secessionist links with the larger art community, which, given the group's desire to legitimate photography as an art, was paramount. Exhibitions of this sort publicly demonstrated the kinship between artistic photography and more traditional media, and provided an artistic context in which viewers could locate Secessionist works. ${ }^{10}$ Best of all, an inclusive exhibition policy served to integrate the Photo-Secession within the art world by forging links between Secessionists and artists in other fields, while simultaneously attesting to its much-vaunted independence from art-world politics and artworld conventions, which dictated that photography and the other arts should occupy separate and distinct spheres. ${ }^{11}$ Thus while the gallery served some of the same purposes of many nineteenth-century photographic galleries-most obviously, the public display of its founder's photographic creations-291 differed significantly from venues such as Mathew Brady's "gallery of great historical figures" and Napoleon Sarony's gallery of actors and other notables in two respects (Orvell 1989, 8-9; 79-81). 291's emphasis on photography's formal and aesthetic qualities, rather than on its subject matter, demonstrated a turn away from previous uses of the medium as a historical, pedagogical or documentary tool. Moreover, Stieglitz's decision to build ties within the art world by demonstrating the links between photography and other media, rather than to reach out to a broader public through appeals to its taste for the famous and heroic, also marked a significant departure from previous practice.

The journal Camera Work served as the linchpin of Stieglitz's enterprise. Although they insisted on its independence, Stieglitz and fellow editor Joseph $T$. Keiley consistently used the journal not only to promote the acceptance of photography as an art, but to keep readers abreast of Secession successes 
and to publicize exhibitions at the Little Galleries. ${ }^{12}$ Not merely an advertising supplement, Camera Work lay at the heart of a more subtle enterprise: Stieglitz's construction of the Photo-Secession as an artistic splinter group, successful for the genius of its works, rather than its dependence on art-world politics. For the many readers who could not experience their exhibitions first-hand, Camera Work was the Photo-Secession. ${ }^{13}$ If the Little Galleries provided an amenable context of display for modernist works, Stieglitz's ability to put a positive spin on all that took place therein ensured that that context extended far beyond the literal space bounded by the gallery walls. ${ }^{14}$ Leaving nothing to chance, Stieglitz supervised artistic production from beginning to end, integrating creation, display, and criticism under one dominion.

Camera Work supported the third element in Stieglitz's empire, the PhotoSecession. Within the first year of publication, the journal's editors devoted a small supplement to answering the "many ... enquiries as to the nature and aims of the Photo-Secession and requirements of eligibility to membership" ("The Photo-Secession," Camera Work 3 [July 1903], supplement). In this periodically updated and reprinted supplement, the editors presented the Secession to the public as a unified movement, dedicated to a singular aesthetic goal, a cohesiveness which the group itself did not always share. By including a "brief résumé of the character of this body of photographers" and a roster of the association's membership along with a statement of artistic purpose, the editors also promoted the group's internal cohesion, providing Secessionists with both a conveniently sanctioned set of self-definitions and a hierarchized index of fellow members with which to describe and locate themselves within the movement.

Comprised of a Council, Fellows, and Associates, the Secession had room enough for collectors, writers, and other supporters, as well as photographers. While photographers always held a primary position within the organization, Stieglitz and his associates recognized the need to forge alliances with sympathetic nonpractitioners. Although the title "Associate" reinforced the distance between makers and mere auxiliaries, Camera Work's editors papered over this distinction by stressing the unity of purpose the two of gaining entry therein. While claiming that associateship demanded "no requirements except sincere sympathy with the aims and motives of the 


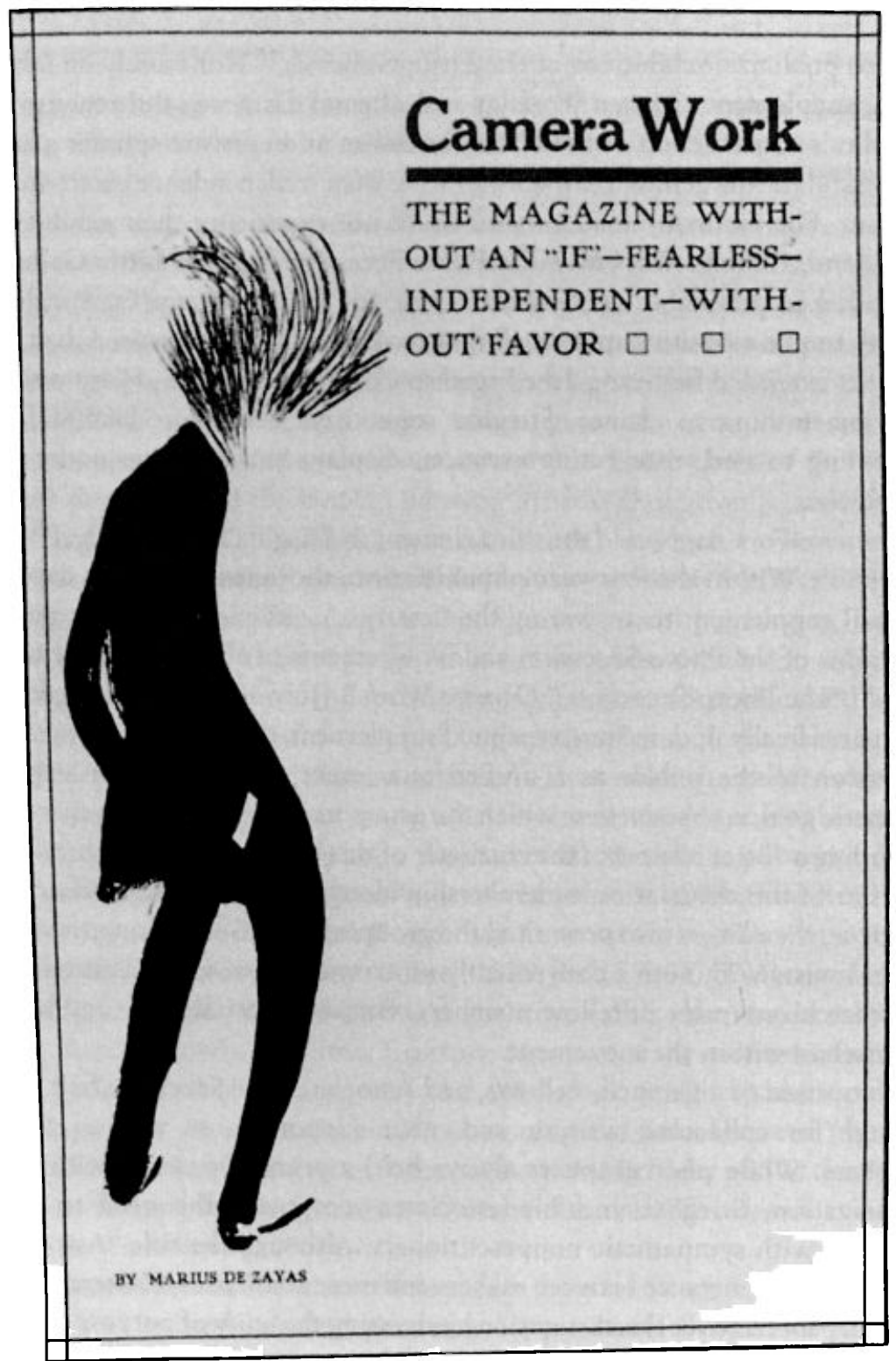

Photograph 1. Marius de Zayas, Camera Work, "The Magazine Without an 'If'” (Alfred Stieglitz), in Camera Work 30 (April 1910). (Photograph made by the Baltimore Museum of Art.) Reprinted with permission of the Baltimore Museum of Art. 
groups shared. ${ }^{15}$ The editors did their best to lend cachet to supporting roles, moreover, by emphasizing the exclusiveness of their ranks and the difficulty Secession," the editors insisted that

it must not be supposed that these qualifications will be assumed as a matter of course, as it has been found necessary to deny the application of many whose lukewarm interest in the cause with which we are so thoroughly identified gave no promise of aiding the Secession.

("The Photo-Secession," Camera Work 3 [July 1903], supplement)

To secure the enthusiastic cooperation of collectors, critics, and other nonartists essential to the secessionist cause, supporters had to be reassured that they, too, "aid[ed] the Secession" in meaningful ways.

The urge to form advantageous alliances outweighed merely professional considerations. Although Camera Work's purpose was, on the most obvious level, to challenge and redefine existing boundaries within the artistic guild in order to make room for photographers, it would be a mistake to interpret the Photo-Secession as simply a fledgling professional association. Camera Work brimmed with demands that photographers be treated as artists. Nonetheless, its writers bristled at the suggestion that artists in other fields could evaluate photography on the basis of their professional experience alone. As a distinct and quickly developing medium, they argued, photography resisted easy assessment even by experienced art-world professionals (Stieglitz 1905, 50-51; Watson-Schutze 1903, 46-47). Cutting short suggestions that photographic juries be made up of painters and sculptors, Camera Work regular Charles Caffin ${ }^{16}$ wrote that

prints that might have passed for notable a short time ago have been superseded in character and quality by later productions; and even among the photographers themselves it is only those who have kept themselves in touch with the important exhibitions that are in a position to judge of the kind of work which should be accepted as representative of the latest phase of the movement. Without such expert assistance a jury of painters and sculptors would hardly prove satisfactory in the judging of photographs, for so few of them have taken enough interest 
to acquaint themselves with the subject. Except as an assistance to their own work, they do not treat it seriously, and their attitude toward a print is generally one of surprise that it should be as good as or no worse than it is. $(1903,44)$

Membership within the photographic profession also did little to guarantee sympathetic or kind treatment in Camera Work. When the well-credentialed professional photographer Julius C. Strauss "presumed to act as spokesman for the photographic pictorialists," Stieglitz quickly undercut his authority. Freely acknowledging Strauss's status as "a well-known professional portraitphotographer," Stieglitz denied that membership in the photographic profession qualified him to speak for the group. "No doubt," the editor wrote,

Mr. Strauss was actuated by what he conceived to be the best interests of photography, and for taking the initiative is entitled to much credit; but his connection with the modern pictorial movement has hardly been such as to have given him the knowledge and experience necessary to impress the authorities with the history and consequent rights of photography as a fine art.

("Pictorial Photography: The St. Louis Exposition," Camera Work 1 [January 1903], 37) ${ }^{17}$

Camera Work's hostility to mere professionalism in photography stemmed from the Secession's desire to be defined differently from other American artists' associations, which often were organized around common professional aspirations rather than shared artistic styles or methods. Like Caffin, Stieglitz described artistic photography as a movement, with rules of association derived from aesthetics rather than professional protocol. As constructed in the pages of Camera Work, the artistic splinter group was a movement which transcended professional boundaries, holding its own within the art world as an organization which simultaneously relied on and denied its integration within that community. ${ }^{18}$

Stieglitz's explanation of Strauss's ineptitude as an interpreter of pictorialism exposes another function of the metaphor of "movement." In questioning Strauss's capacity to speak in "the best interests of photography," 
Streglitz first excluded Strauss from commenting on the "modern pictorial movement." Quickly, though, he extended this ban to all artistic photography, questioning Strauss's familiarity with "the history and consequent rights of photography as a fine art." By blurring the distinction between the two, Stieglitz expanded Secession terrain to include not only their own productions, but all artistic photography. Moreover, he expanded their role beyond the production to the interpretation of artistic works, claiming exclusive right to photography's history, as well as its future. By drawing boundaries between Secessionists and professionals in this way, Stieglitz both laid the basis for Secession unity through self-interpretation, and helped to exclude alternative visions of the possibilities for artistic photography.

Stieglitz's formation of an elaborate matrix of institutional support for the pictorialist project attests to his profound debt to organizational developments in the Gilded Age art world. Convinced that America's clearest path to artistic greatness lay in the establishment of institutions devoted to the display, dissemination, and explication of art, Gilded Age art lovers dotted the landscape with museums, schools, and critical outlets (Harris [1966] 1982, Horowitz 1976, Miller 1966). Although nineteenth-century institution builders had generally represented the connection between organization and artistic results in rather vague terms, proposing that greater public art consciousness fostered by new museums, for instance, would contribute to a generalized improvement in American artistic production, some artists' groups recognized organization's more tangible potentials. While these groups generally relied on association for their strength, they occasionally turned to criticism as well. The Society for the Advancement of Truth in Art, thus, relied heavily on its journal, the New Path, in its campaign to transform American art (Ferber and Gerdts 1985).

The Photo-Secession's organizational structure reflected Stieglitz's thorough understanding of the need for a multilayered, institution-building approach to successful artistic production. ${ }^{19}$ Stieglitz himself had broken new ground in this respect, attending to the 1896 merger that had created the Camera Club, New York, and saved the New York Camera Club and the Society of Amateur Photographers from stagnation (Peterson 1993, 12-16; Homer 1983, 34-39). Stieglitz also took charge of the group's journal, Camera Notes, hoping that the regular publication of criticism, examples of good 
photographic work, and information about the club and "what is going on in the photographic world at large" would inspire creative advances among its readership (quoted in Peterson 1993, 16).

In Camera Work, Stieglitz recognized a new and powerful use for criticism, surpassing Gilded Age practice in significant respects. Unwilling to embrace fully the methods of his predecessors, who had used criticism to promote not only the development of particular art institutions but the importance of institution building per se, Stieglitz used criticism to more complicated ends. Denying the importance of institution building to artistic production, Stieglitz used Camera Work to create a fictional institution as powerful as the museum, the market, or any of its nineteenth-century predecessors: the avant-garde. If Gilded Age writers had seen criticism as the glittering thread which tied institution to institution, which bound artist to art world, and which drew the observer's eye to the brilliant fabric that resulted, the Secessionists understood that criticism could be used just as easily to opposite ends. While Stieglitz and his associates wove collectors, artists, and critics together, the thread spun by Camera Work concealed rather than revealed. In their hands, Camera Work produced not art-world unity, but the myth of non-affiliation.

\section{"The Safeness of Standing Alone"}

If Stieglitz was to deny the organizational roots of pictorialism's success, it would not have served his purpose to portray the Photo-Secession as merely an improvement upon or surrogate for existing art-world organizations. Throughout the nineteenth century, a succession of rebel groups had emerged within the American art world, each claiming to overthrow the stale methods of the "establishment," and to represent artists' true and future needs (see Morgan 1978). They sought to replace the "establishment," however, with new institutions. As it turned out, most of these associations eventually developed an unhappy resemblance to their predecessors, falling into comfortable routines of nepotism and sterility and spurning new works in favour of the tired productions of already established members. ${ }^{20}$ Just decades after its founding in the $1870 \mathrm{~s}$, for example, the Society of American Artists was shedding its own splinter groups such as the Ten, who no longer believed 
that the association provided an environment suitably distinct from that of the Academy (Gerdts et al. 1990).

Stieglitz proposed something different. While Camera Work did reveal the conventional aspects of the Photo-Secession's structure-division into multiple layers of membership, special distinction for artistic members, membership by selection-the editors also used the journal to construct the Secession as a different kind of entity, reliant solely on aesthetic sympathy for its cohesion. ${ }^{21}$ Caffin promoted this vision most succinctly, arguing that "The Photo-Secession, in fact, is all that one particular strong personality stands for, syndicated" (Caffin 1907a, 27). Caffin's attribution of Secession imperative to a single, unified will masked the complicated negotiations within the photographic community that had determined the group's membership, diverting attention instead to the group's aesthetic principles. ${ }^{22}$

Nonetheless, it still suggested that one dominant personality (Stieglitz's) might have forced the rest to submit. Stieglitz's own analysis of the Secession's character thus further underplayed its organizational aspects, both avoiding the use of organizational metaphors (syndication) and eschewing all suggestion of the group's dominance by any one individual. Displacing agency onto a vague spirit of honesty, Stieglitz described the Photo-Secession as the

Spirit of the Lamp; the old and discolored, the too frequently despised, the too often discarded lamp of honesty; honesty of aim, honesty of selfexpression, honesty of revolt against the autocracy of convention. The Photo-Secession is not the keeper of this Lamp, but lights it when it may. ("The Editors' Page," Camera Work 18 [April 1907], 37-38)

By insisting that the Photo-Secession was an aesthetic movement rather than an organization, Stieglitz distanced himself from Gilded Age reliance on institutions as the tools of artistic progress, and was able to naturalize his own aggressive role in the group's formation. By identifying his organization with European Secession movements which had overtly criticized the market, moreover, Stieglitz was able to rhetorically mask the Photo-Secession's profound indebtedness to corporate sponsors such as Kodak. ${ }^{23}$ Thus Stieglitz set the stage not only for the devaluation of institution building as a viable route 
to artistic progress, but for the naturalization of artistic production under the avant-garde.

If, in describing the Secession as a single-minded "Keeper of the Lamp," Stieglitz treaded lightly on the issue of the group's organizational characteristics, other writers boldly denied any such attributes to the association. Paul Haviland, for one, exclaimed that

we are dealing, not with a society, not with an organization, as much as with a movement. The Secession is not so much a school or a following as an attitude towards life; and its motto seems to be:- 'Give every man who claims to have a message for the world a chance of being heard.' $(1909,22)$

Once again, Camera Work's metaphorical description of the Secession as a movement, rather than a formal association, both provided the rhetorical basis for Secession unity through common practice, and argued for its unique claim to "honest," free, and therefore natural production. Affiliation with a movement had pay offs for participants, as well, rhetorically uniting disparate producers and allowing them to forget the more earthly components of the artistic life-political intrigue, the constant struggle for fame and success-in favour of a purer notion of artistic production.

In 1906, the Photo-Secession achieved a milestone in its struggle to gain acceptance for photography as an independent artistic medium: an invitation to mount an exhibit at the Pennsylvania Academy of Fine Arts. The academy had, after all, "helped to initiate the Salon movement in Philadelphia," only to close "its doors on the photographers and their claims" a few years later (Keiley 1906, 49-50). A sign of the Photo-Secession's coming-of-age, this invitation inspired Camera Work insider Joseph T. Keiley to pen a brief history of the group, in which he trumpeted Secessionist triumphs and set the stage for its future accomplishments. ${ }^{24}$ Keiley did more than merely document the Secession's arrival, however; under the guise of recounting the group's past affairs, he used his critical history actively to shape and mould its identity. Burying the organizational content of Secessionist activity under a barrage of claims about the group's independence, Keiley transformed a moment of patent institution building into evidence not only that the group 


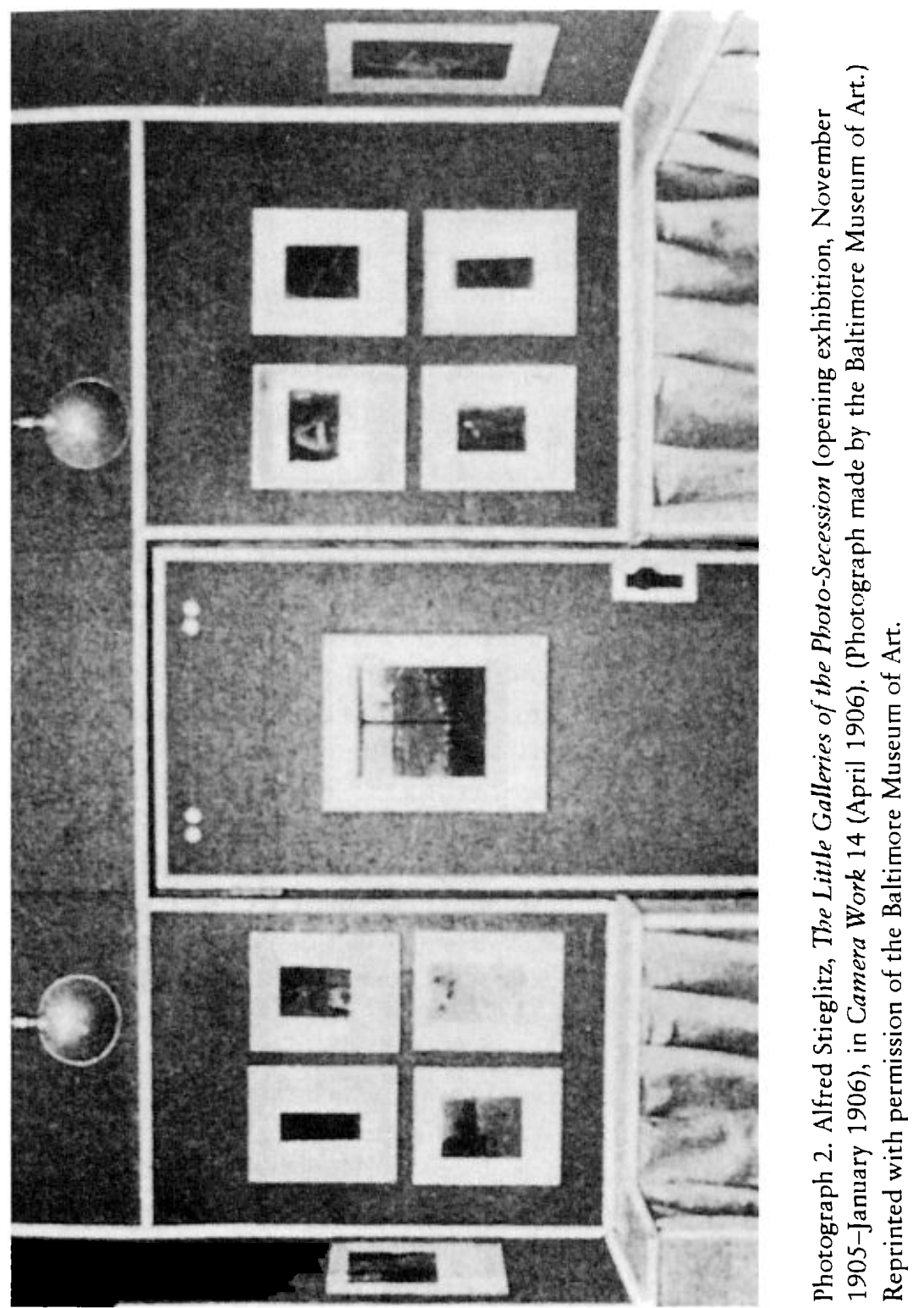


had stood apart from the surrounding art world, but that its autonomy had guaranteed its success.

Even though his announcement heralded the fact that a hallowed arts institution had agreed to support and shelter the Secession, Keiley maintained that the invitation proved the Photo-Secession's remove from art-world intrigue (Keiley 1906). The Photo-Secession, he wrote,

had kept apart from all entanglements with other organizations. Effort was repeatedly made to affiliate it with other organizations, or to draw it into controversy. Experience had taught it the lesson of the safeness of standing alone. Into controversy or politics it always declined to enter. On the other hand, it opposed no recognition, and sought to secure it for its own exhibitions. (1906, 49-50)

By presenting independence as the cause of present and indisputable events (the Photo-Secession's current success, exemplified by the Pennsylvania exhibition), Keiley lent it the force of historical fact. In this way, Keiley surpassed the celebratory and promotional rhetoric endemic within Gilded Age criticism, positing a new relationship between critics and the events at hand. Most Gilded Age writers had rendered their observations about the art world rather transparently, perhaps noting the place of particular events within the larger trajectory of American progress in the arts. Keiley's history had a more definite endpoint. Keenly aware of the invitation's potential to confirm a larger set of claims about the Photo-Secession and pictorialism generally, Keiley transformed it from a simple marker of success into evidence for the group's independence from art-world affiliations, and for its single-minded adherence to an aesthetic, rather than a political, goal..$^{25}$

Stieglitz and his associates employed a wide variety of rhetorical strategies to shape an independent Secession. Powerful among them was the editors' consistent appeal to a central dichotomy by which they judged all opportunities for exhibition. Camera Work divided exhibition situations into two clearly marked categories: those in which the Photo-Secession was free to display its works, unencumbered by outside interference, and those in which the taint of external meddling prohibited viewers from experiencing pictorialist works in the correct manner. Insisting that the Secession itself have 

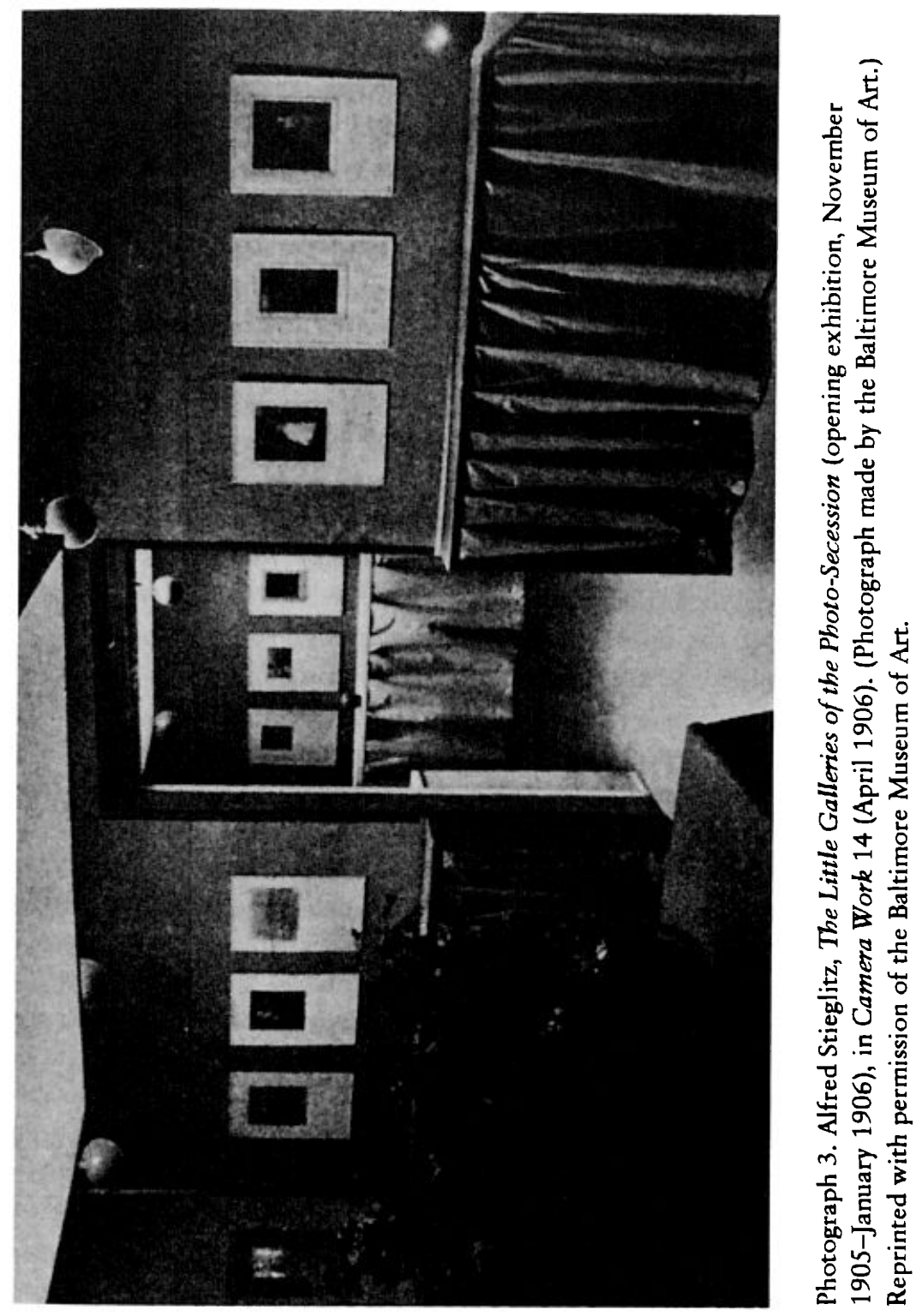
full control over the judgment and selection of its members' productions, Camera Work announced in 1903 that "it is the policy of the Photo-Secession to exhibit only upon invitation, and this necessarily implies that its exhibit must be hung as a unit and in its entirety, without submission to any jury" (Editors 1903b, 50). Such proclamations emphasized the unity and impenetrability of the Photo-Secession, while warning trespassers to respect its boundaries. ${ }^{26}$ If the Secession worried that juries' invasive appraisal of its members as individuals would compromise its independence, it also fretted that outside organizers lacked the capacity to show photography to its best advantage. S. L. Willard expressed this fear in the journal's second issue, writing of the Third Salon at Chicago that

remarks on juries and on hanging may seem less pertinent than a criticism of the prints; but a poor setting will mar a good play; cheap typography and binding a good book; inexperienced performers an artistic musical composition. Pictorial photography may well claim a place among fine arts, but dignity and sanity are needed in its every relation if it is to attract the approval and recognition of people of taste and cultivation. $(1903,49)$.

By relinquishing its works to the inexpert hands of outsiders, Willard suggested, the Secession would never be able to convince the world of photography's true merit.

Stieglitz's appeal to "independence" as the standard for Secession entry into exhibitions served several purposes. It allowed him to explain the Secession's uneasiness concerning competing institutions, and enabled him to distance the group from the many friendly associations it had made. Moreover, it allowed Stieglitz to perform this distancing while continuing to portray the approval of these outside groups as evidence of the Secession's merit. In describing Secessionist participation in exhibitions outside the Little Galleries, the editors oscillated between self-congratulation for having been recognized by galleries, critics, and other art-world players, and carefully placed barbs about the inadequacy of non-Secessionists to make aesthetic decisions. In assessing one of "the two most important exhibitions of pictorial photographs held in recent years in this country ..., at the Corcoran 
Art Galleries in Washington and at the Carnegie Art Galleries in Pittsburg [sic] in February," Camera Work announced that

at Pittsburg the interest is equally great, the exhibition being still open at this writing. In order to insure the complete carrying out of our ideas, the Director of the Photo-Secession, accompanied by Messrs. Steichen, Keiley, and Coburn, traveled both to Washington and Pittsburg to superintend the hanging of the prints, a matter of great importance which is generally underestimated, as well as formally to open the halls to the public. The local press showed much interest, devoting a large amount of space with the usual inadequate newspaper illustrations to the Secession and all its works.

("Photo-Secession Notes," Camera Work 6 [April 1904], 39)

Disguised by their mildness of tone, and inserted within the larger, congratulatory framework of tributes to Photo-Secession success, these criticisms nonetheless hit their mark, proving the distance between Secessionists and their peers.

Camera Work's dichotomization of independence and interference served another crucial purpose, explaining and naturalizing the founding of the Little Galleries. The development of internal structures for the dissemination and display of Secessionist productions lay at the heart of the group's success, drawing attention from all corners of the art world and providing a physical locus for promoting the group's cohesion. Stieglitz and his associates insisted, however, that the significance of the Photo-Secession's organizational activity lay in only one, particular, result: the establishment of a "neutral" and "independent" space in which "quality" alone determined content, ${ }^{27}$ and in which viewers could encounter pictorialist works without the taint of outside prejudice or politics. ${ }^{28}$ This had been necessary, Keiley argued, because "academic and art-organization exhibitions, with few exceptions, have degenerated into being conservators of aesthetic snobbery or of the commercialization of art" (Keiley 1911, 23). Casting all outside involvement, even on the part of friendly parties, as a hindrance to the proper display of pictorialist works, Camera Work argued that the creation of a wholly Secessionrun exhibition environment was not only desirable, but absolutely necessary 
for pictorialism to thrive. By developing a rhetorical context in which "Secessionist" came to stand for "independent," Stieglitz and his associates emptied the Little Galleries of all contextual import; in the presumably neutral space of the Little Galleries, the editors suggested, works spoke loudly, clearly, and forcefully for themselves, necessarily winning an audience of thrilled supporters. In this way, Camera Work transformed an organizational issue-how to promote and disseminate art works-into a purely aesthetic matter, independent of its institutional context.

In reality, Stieglitz and his associates paid close attention to the details of display, creating contexts that enhanced the reception of Secessionist productions and distinguished Photo-Secession exhibitions from those of its competitors. ${ }^{29}$ Besides arguing for photography's inclusion among the fine arts through a concurrent display of drawings, paintings, and photographs, ${ }^{30}$ Stieglitz surrounded Secessionist productions with the conventional trappings of artistic display. This gained him the scorn of critic Charles Fitzgerald, who sneered that

the exhibition at present open at No. 291 Fifth Avenue is simply reeking with 'art' down to the very catalogue with its eccentric lettering, its pretty little gold seal, and its ragged edges. There is surely nothing wanting in the way of refinements; if there is a question, it is whether all these excrescences are traceable to a foundation as solid as the photographers would have us believe. They suggest, not the struggles of exploration, but the easy satisfaction of established convention, not to say the refinement of decay. ([1905] 1906, 33)

More important than the catalogue was Stieglitz's manipulation of the physical environment of display, which Stieglitz used to distinguished PhotoSecession exhibitions from those of its contemporaries. As early as the 1870 s, artists in Europe and the United States had challenged contemporary modes of display, arguing that crowded walls and the "skying" of certain paintings above beholders' line of sight had prevented many works from being adequately seen, and that the placement of insiders' work "on the line"reinforced academy-sponsored hierarchies. In response to this, as much as to outright rejection, many artists had called for a radical revision of ex- 


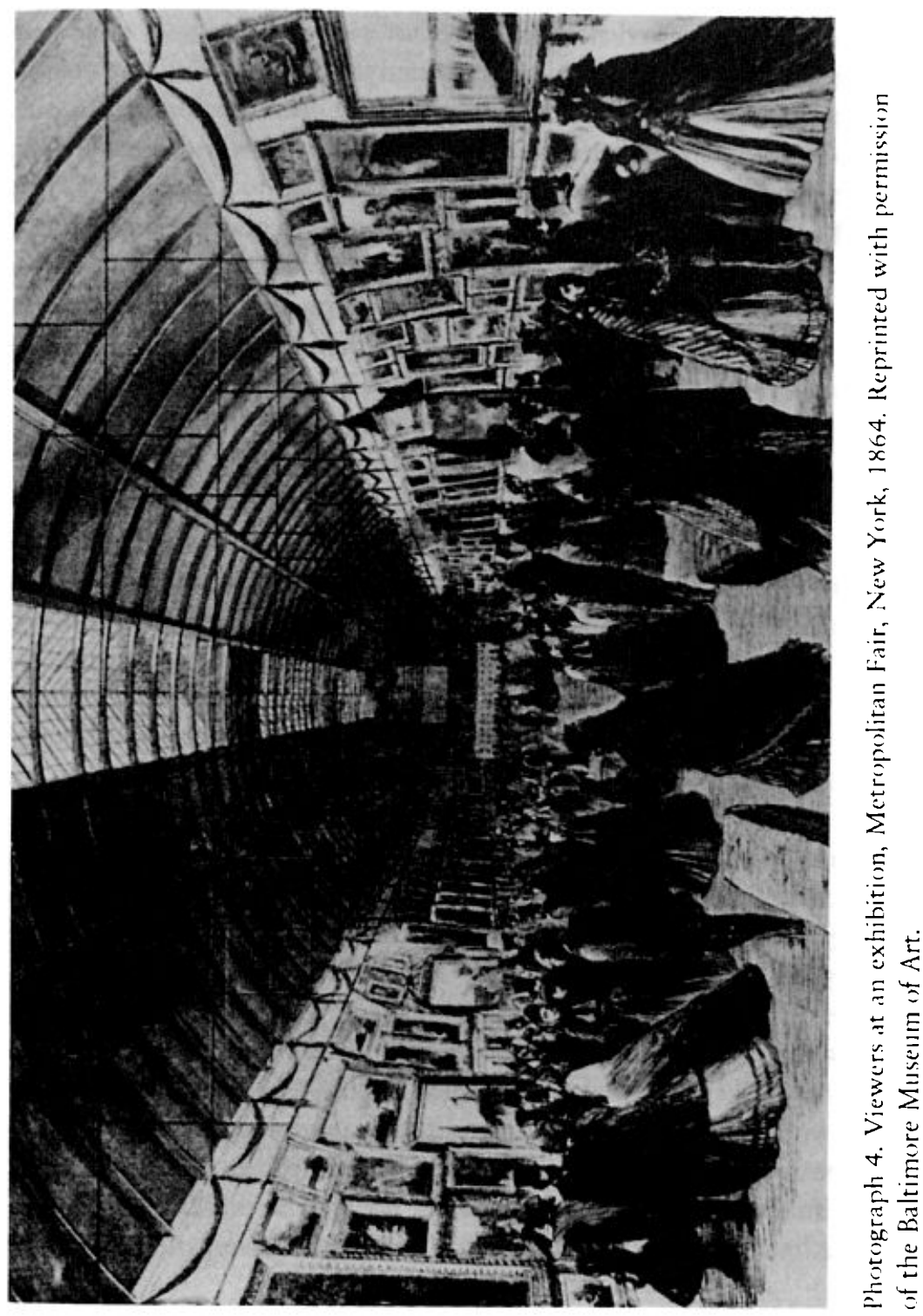


hibition practices. From the 1870 s onward, for example, James McNeill Whistler staged a series of exhibitions which showcased his own work within a context entirely of his own invention. ${ }^{31}$ Leaving no details to chance, Whistler not only directed the placement of pictures-hung in single or double file across the line of sight - but selected frames, materials and colour for the walls, and the design and content of exhibition catalogues. In one case, the artist even instructed guests to wear black and white, so as not to disturb his carefully devised colour scheme. ${ }^{32}$

While Whistler provided a well-known alternative to conventional modes of display-he had orchestrated two shows in New York in the 1880sStieglitz followed his example only in part. Although Whistler's exhibitions had emphasized harmony between works and their environments, his intention was never to efface context entirely. The Whistlerian exhibition was always an event. In contrast, Stieglitz hung works sparsely within a minimally decorated, neutrally coloured space (see photographs 2 and 3), thereby not only distinguishing exhibitions at the Little Galleries from spectacularly crowded Academy-style shows (see photograph 4), ${ }^{33}$ but bolstering claims that the Secession's only concern was the production of meritorious works. This physical simplification of exhibition settings again enabled the naturalization of the Secessionist context of display, by presenting a carefully constructed environment as proceeding logically from works themselves. Supporting this view, Caffin suggested that the contextlessness could be an exhibition's primary virtue, writing of one show that "I have never seen an exhibition presented with so discreet a taste.... The secret of its discretion ... consisted in adopting the photographic print itself as the unit of the scheme of arrangement. This sounds obvious enough, but observe the result of conforming to it logically" (Caffin 1906, 33, emphasis added). ${ }^{34}$

The cry of "independence" helped to mask the full importance of Secessionist involvement in outside exhibitions, as well. As Keiley described it, the Exhibition at the Pennsylvania Academy possessed a special "Place and Significance" in the history of the Photo-Secession because it had provided the group with a powerful opportunity to display its work but had compelled the organization to "surrender no ground gained" (Keiley 1906, 50). The Photo-Secession demanded control over the context of exhibition to avoid undue interference, to be sure; equally important, however, was their need 
for the conventional trappings of artistic display. The contrast between Photo-Secession reaction to the terms of participation at Philadelphia and at the St. Louis World's Fair demonstrates Stieglitz's realization of the profound degree to which the context of display influenced works' reception. The Pennsylvania exhibition provided the group with an opportunity to explain and promote a pictorialist, Secessionist platform; moreover, it offered it an amenable and overtly 'artistic' institutional backdrop, and, equally important, a degree of control over the interpretive space of the exhibition catalogue. The academy, in short, offered the chance to present a united and exclusive front, and marked Secessionist works unmistakably as artistic creations. In contrast, participation at St. Louis would have demanded the dispersal of the group's oeuvre among the lesser productions of nonmembers. As photographs, the Secessionists' works would have been banished from the Fine Arts section at St. Louis, made to stand not with paintings or etchings, but with the productions of professional portrait photographers and other hacks. Not surprisingly, Stieglitz boycotted the St. Louis exhibition, describing the decision of some pictorialists to participate as "a pity" ("PhotoSecession Notes-St. Louis," Camera Work 5 [January 1904], 50).

Stieglitz's real innovation was to expand the Secessionist context of display beyond the gallery walls, to fit the much less tightly bounded space created by Camera Work, and to use this enlarged context to direct observers' responses to Secessionist productions. (All the while insisting, of course, that the Secession's admirers had come to judgment through direct and unmediated interactions with its works.) Stieglitz used Camera Work as an alternative forum for the dissemination of Secessionist works, the main attraction of the journal being its many high-quality photographic plates. ${ }^{35}$ Indeed, the editors insisted that the plates deserved the same attention as any original prints displayed at exhibition. ${ }^{36}$

While Camera Work served, in a literal sense, as an extension of 291, Stieglitz also used the journal to build and broaden the discursive context of Secessionist display. ${ }^{37}$ To do this, Stieglitz relied not on the group's independence, but on the reputation of others within the art world. Like Gilded Age writers who had drawn attention to friendly European responses to the Centennial Exhibition and other signs of American progress in the arts, Stieglitz traded on the reputation of Europe as the capital of art, frequently 
noting positive European criticism of the Secession. ${ }^{38}$ Continuing sensitivity to America's position of obscurity within the international art scene diminished the likelihood that readers would challenge praise from such lofty quarters. To preempt charges of arrogance for having so often repeated these words of acclaim, and as a means of reinforcing their own disentanglement from their authors, Camera Work's editors mincingly refrained from printing them all, writing that

in recent numbers we spoke of printing some reviews of the PhotoSecession Invitation Collections which had been sent to various European capitals. We had hoped to publish in this number extracts from these articles, but upon mature consideration have deemed it best to omit them. The Photo-Secession and its workers have so often been accused of over-weaning arrogance and conceit that the eulogistic tone of all these critiques would seem, if reprinted by us, to lend some truth to these charges, and therefore, to save our modesty, we feel constrained to forego publishing these reviews.

(Exhibition Notes," Camera Work 11 [July 1905], 57)

In case critical tributes did not prove to readers that the Secession was a contender, the editors also frequently inventoried the many reputable institutions who had thrown their support pictorialism's way. ${ }^{39}$ To ensure that such references would not be taken as mere toadying to the art-world establishment, Camera Work also contributed a helpful index of well-known rebel groups with which readers could associate the Secession. ${ }^{40}$

An innovative editorial strategy supported Camera Work's rhetorical appeals to independence, arguing not only for the sovereignty of the PhotoSecession, but the autonomy of the journal itself. Avoiding a fixed staff, Stieglitz peopled its pages with a constantly evolving cast of critics, devoting only a limited amount of space to official, editorial opinion. Not satisfied with the mere solicitation of outside views, the editors often reprinted large blocks of text directly from competing publications. Implying that Camera Work had escaped from even their own control, the editors expressed a "wish to reiterate for the nth time that the articles published in the magazine do not necessarily reflect [ou]r own views. As a matter of fact, few of them do. It has 
been our policy-and it will continue to be our policy-to print such articles as we deem timely, interesting, or provocative of ideas" ("Our Articles," Camera Work 17 [January 1907], 41).

In truth, Camera Work did supply readers with a wide array of views on artistic and photographic issues, not all of them friendly. The journal's critical "regulars," moreover, did not cheer unceasingly for the Secessionıst cause. The usually sympathetic Caffin brandished his own critical independence, lacing his commentaries with acerbic expositions on the egotism and folly of artists, photographers included. ${ }^{41}$ Although roomy enough for multiple voices, Camera Work was hardly a haven for dissent. Printing hostile views, but certainly not embracing them, the journal's editors took steps to ensure that readers could distinguish challenges from the "party line." More than willing to flex editorial muscle to keep unruly opinions in line, the editors enforced these distinctions through a complex strategy of editorial contextualization. This strategy enabled readers to locate the relationship not only of particular authors to the Secessionist core, but to determine the proximity of their individual views to current Secession opinion. While allowing Stieglitz to marginalise the views of the Secession's critics, this strategy also provided a powerful mechanism by which to mask the bonds between friends. If the Secession were to pass as an autonomous association, independent of politics, intrigue, or influence, this was of critical importance.

Camera Work, for example, frequently contained numerous "outside" reviews of important art-world events. The publication of these commentaries, culled from disparate sources and printed serially, signalled Secession confidence and nonchalance concerning art-world squabbles. Yet, if the presence of these outside views demonstrated the Secession's willingness to take on all comers, their presentation told a very different story. Often printed in much smaller typeface than the surrounding sanctioned text, these extracts usually succeeded a brief introduction that provided readers with the keys to deciphering and distinguishing between the narratives that followed. Publishing a panorama of responses to the 1908 exhibit of Rodin drawings at the Little Galleries, thus, the editors prefaced the extracts with the following exclamation: "It may be said to the credit of New York-provincial as it undoubtedly is in art matters generally - that in this instance a truer and more spontaneous appreciation could nowhere have been given to these 
remarkable drawings" "The Rodin Drawings at the Photo-Secession Galleries," Camera Work 22 [April 1908], 35). In case this recommendation (or the fact that the exhibition was held on the Secession's home turf) did not sufficiently colour readers' expectations, the editors also reprinted the text of the catalogue in full, "for the benefit of the readers of Camera Work who did not have the pleasure of seeing the exhibition" ("The Rodin Drawings at the Photo-Secession Galleries," Camera Work 22 [April 1908], 35). Thus, even before the first "outside opinion" was cast, the editors had set up a powerful and encircling context for its reception. ${ }^{42}$

The editors sometimes extended this strategy of contextualization to the sequence of "outside" views, as well. In the Rodin piece, they arranged reprinted extracts in descending order of sympathy to Secession opinion, with the most outré views lamely bringing up the rear. ${ }^{43} \mathrm{~W}$. B. McCormick thus griped with only seeming impunity that

'these drawings should never been shown anywhere but in the sculptor's studio, for they are simply notes dashed off, studies of the human form-chiefly of nude females-that are too purely technical to have much general interest except that of a not very elevating kind. Stripped of all 'art atmosphere' they stand as drawings of nude women in attitudes that may interest the artist who drew them, but which are not for public exhibition. ${ }^{44}$

Coming on the heels of J. N. Laurvik's assertion that the exhibition was " a challenge to the prurient purity of our puritanism," McCormick's rant against depictions of "nude females" of a "not very elevating kind" proclaimed him as a censor. ${ }^{45} \mathrm{~J}$. E. Chamberlin's contention that the show was "of very great importance to artists and sculptors, though doubtless it will be pretty nearly incomprehensible to the general public," an opinion affirmed by Arthur Hoeber, further prepared readers to mark McCormick as a man out of the know. ${ }^{46}$ Prudes and outsiders may have borne the heaviest brunt of contextualization, but insiders who expressed unsympathetic views were also susceptible to criticism. When Caffin's steady support wavered, the editors quickly stepped in, labelling one of his most virulent attacks on artists "As Others See Us" (Caffin (1905, 25-26). Similarly, Camera Work's editors 
undercut Caffin's critical authority on specifically aesthetic issues, particularly when Caffin failed to express core doctrines of the Secession. ${ }^{47}$

Contextualization-or, what might more properly be called decontextualization-also worked to dissolve the ties that bound sympathetic writers to the Photo-Secession. The editors worked hard to demonstrate that the "independence" of Camera Work's writers was compromised neither by excessive intimacy with the Secession nor too much political clout within the art world. Thus, in introducing Caffin's critical debut in the new venue, Stieglitz contrasted his open-minded treatment of pictorialism to Julius Strauss's grandstanding on the subject. Caffin's inclusion, Stieglitz suggested, promised not only more intelligent readings of pictorialism, but the potential for provocation disabled by Strauss's comfortable position within the profession.

Pictorial photography having at last won recognition in recent European Art Exhibitions, the managers of the St. Louis Exposition have awakened to the fact that they could no longer ignore its claims; although, until Mr. Caffin, the art critic and editor of the American section of The International Studio, took up the cudgels for the cause, the authorities in St. Louis seemed bent upon following the old narrow path. Nor were they entirely unjustified in their conservatism in view of their lack of knowledge of what had been accomplished in this medium.

("Pictorial Photography: The St. Louis Exposition," Camera Work 1 [January 1903], 37)

While Stieglitz admitted that Caffin had displayed prior sympathy with the Secession's aesthetic aims, he carefully avoided mention of the critic's longstanding affiliation with Camera Notes. Treating Caffin's views as found objects rather than the opinions of a trusted companion, the editor obscurely wrote that "Mr. Caffin has covered the ground so admirably in The International Studio, and represents so thoroughly the spirit we stand for, that we feel that we can do no better than present it to our readers in its entirety" (Pictorial Photography: The St. Louis Exposition," Camera Work 1 [January 1903], 37). 


\section{The Undoing of the Public}

Although editorial sleight-of-hand effectively masked the relationship between the Photo-Secession and its critical admirers, Camera Work generally employed more subtle means to deny the organizational roots of pictorialism's success. Emptying the act of looking of all contextual content, Stieglitz used Camera Work to redefine the process by which observers came to form judgments about works. Camera Work overturned nineteenth-century critics' definition of critical knowledge as an accretion of years of study and reflection, representing judgment as a blistering moment of revelation in which works alone won viewers over without their consent, much less their consideration. ${ }^{48}$

Stieglitz's promotion of the contextually neutral "moment of revelation" as the key to taste formation had powerful consequences not only for the American art world in its narrowest sense, but for all Americans whose lives might have been affected by the making and consuming of art. By denying the importance of Secessionist institution building, Stieglitz was able to attribute the group's success entirely to its artistic productions. In this way, Stieglitz helped to initiate a modernist art criticism which promoted the making of aesthetically "superior" objects as the primary and exclusive goal of artistic activity, and which located the primary source of artistic meaning in artistic objects, rather than within complicated interactions between viewers and works. ${ }^{49}$ Not coincidentally, Camera Work also offered a radically curtailed definition of the "public" for art, continuing a process of diminution begun by professional critics before the turn of the century. ${ }^{50}$

In the pages of Camera Work, the infinitely educable public promoted in the 1870 s finally gave way to a full-fledged aristocracy of taste, exemplified by Sadakichi Hartmann's ${ }^{\text {st }}$ assertion that

the Secessionists care little for popular approval, insisting upon works, not faith, and believing that their share having been done in producing the work, the public must now do the rest. A few friends, and these of understanding mind, a few true appreciators, this is all they expect and all they desire. $(1904,47)$ 
The avant-garde aristocracy of vision promoted by Stieglitz and his associates differed significantly from taste hierarchies operative since the $1870 \mathrm{~s}$. To be sure, institution-building writers in the period after the Civil War valued the opinions of some observers over others, tending to give credence to those who, like themselves, had earned their say through years of art-world activity. These writers never suggested, however, that critical facility stemmed purely from talent or other "natural" roots, or that differences in the "natural" abilities of observers could not be overcome. To post-Civil War writers, education provided the single most important source of perceptive skill. Although Caffin described public perception elsewhere as educable, malleable, and open to improvement, Secessionists generally upended this assumption, raising "naturally" occurring insight in its place.

Deliberately, Camera Work's contributors denied the role of education in the formation of critical facility. Hartmann, for one, scorned the thought that the public could ever appreciate "an art as virile and fascinating, individually local and bitter as that of this Montmartre bohemian [Toulouse-Lautrec]," growling that

art appreciation can not be taught. It may be fostered, gradually developed in some naturally responsive and neglected individual, but even then it will lack freedom and spontaneity. Appreciation is an individual growth, like art itself, and it necessitates inborn talent from the start.

For that reason art is by the few and for the few. The more individual a work of art is, the more precious and free it is apt to be; and at the same time, as a natural consequence, the more difficult to understand. $(1910,37)$

Hartmann's bald assessment of the sources of critical acumen placed criticism on the same creative plane as artistic production while assaulting the public's authority to judge and appreciate art. But, although he denigrated the public for a lack of natural critical facility, he also complained that laziness, and not inborn deficiency, had kept the public from fully exercising its opportunity to judge art. Because art required vigorous thought, Hartmann maintained, most Americans had simply abandoned it in favour of music, film, and other more passive enjoyments. "Works of art," he wrote, 
are generally so high-priced that they are beyond the means of the middle class. And merely to study them is too much of an intellectual exertion. People understand a Tschaikowsky symphony as little as an Impressionist exhibit, nevertheless ninety-nine out of a hundred will prefer to hear the concert, while one solitary individual will derive a similar pleasure and satisfaction from the paintings, for the simple reason that music is easier to enjoy. One pays a comparatively small admission, sits down and listens, and the music drifts without any personal effort into one's consciousness. $(1912,19)$

Hartmann's promotion of a visible critical elect chipped away at public participation in artistic judgment. In defining the sources of artistic meaning and enjoyment, however, this critic and self-conscious literary agent was unwilling to relinquish too much agency to works alone. Although Hartmann proposed that the critic derived his capacity to judge and enjoy art from natural, rather than learned, sources, he refused to describe this talent merely in terms of a capacity to receive predetermined impressions.

Caffin demonstrated a similar reluctance to abandon critical agency completely, failing to analyse explicitly the process by which he himself had come to admire Secessionist productions. Although he frequently referred to his judgments as "impressions," his actual meaning for the metaphor was never clear. Notwithstanding his reluctance to erase his own involvement in the production of artistic meaning, Caffin did reassign agency to works when describing the critical activity of others, thus disguising the organizational roots of the Secession's success. Despite devoting years of his own labour to building audiences through criticism, Caffin argued that "The PhotoSecession has passed over the heads of the critics and directly reached the public" (Caffin 1907c, 27). His comments on the physical context of exhibition at the Little Galleries reinforced this line of argument, removing the hand of organization from Secessionist display much as it had erased the impact of criticism (Caffin 1906, 33). In this way, Caffin masked the organizational activity which had made display possible, constructing the Little Galleries as a contextless space in which works alone determined their reception. 
While career critics like Hartmann and Caffin hesitated to remove the production of artistic meaning from the contested ground between viewer and work to works themselves, J.M. Bowles expressed no such reluctance. Denying that his actions or sympathies had played the slightest role in his admiration of the Secession, he wrote that

I am merely an interested and sympathetic outsider. At the outset I was neither for nor against photography; it made its way with me solely by the sheer force of good work. My mind was open-'a fair field and no favor' being my creed in matters pertaining to art-and I hope to be able to keep it so. (1907, 17, emphasis added)

Again, here, Camera Work repudiated the importance of context in the formation of aesthetic judgments, obscuring Bowles's position within the art world (his comments were not accompanied by an explanation of how an "outsider" had come to arrive at the chance to express his unschooled opinions in the pages of the foremost photographic journal of the time) and dismissing the impact of the particular context of the works' display. ${ }^{52}$

Unlike Hartmann, who had depicted the Secession's appreciators as "friends" and abettors of the cause, Bowles suggested that his appreciation had flowed freely from works themselves, without the benefit-or detriment -of outside influence. Bowles wrote that his judgments had come to him

uninfluenced by any reading or 'talk' on the subject. In fact, I have deliberately refrained from informing myself on many points which have arisen in my mind since I started to prepare these notes, because the purpose of this paper is to record emotions produced on a rank outsider solely by the work. My very ignorance may have its value, perhaps even show which way the wind of public opinion blows, and blazon the way for a campaign of publicity upon points regarding which the genuinely interested should be informed. (1907, 17-18)

To Bowles, the meaning of art was not produced by the struggle between autonomous viewer and work, but was produced "on" the emotions of passive viewers "solely by ... work[s]." By relocating meaning's production 
within works, rather than within open-ended, individualized interactions, Bowles not only stripped individual viewers of agency, but of individuality. More importantly, Bowles's account posited "ignorance" as the standard condition of observers, implying that similarly ignorant observers experienced works in similar ways. This assumption allowed Bowles to merge his experience with the general experience of an unspecified "public," about whose opinion he could safely speculate. Once free to act as its mouthpiece, Bowles overturned the meaning of "public opinion."

This had dangerous consequences. Although Bowles posited the "public" observer as an ignorant observer, he did not suggest that the "public" for art included just anyone. In Bowles's formulation, only a small number of people were able to grasp the meaning and significance of art works, and those who could not could never be educated to do so. Thus in calling for "a campaign of publicity," he hardly suggested that the Secession blanket the nation with didactic literature on the principles of artistic photography to prepare future audiences for their interaction with the medium. Instead, Bowles pressed a notion of "publicity" which had little to do with building an audience for pictorialism, but which instead indicated the management of a self-selecting audience whose approval was already known. Bowles thus reversed Gilded Age criticism's understanding of the relationship between education and perception, positing "publicity" as a gloss, after the fact, on those localized elements that vision alone had not made clear, and "genuine interest" as a condition determined not by an observer's curiosity, but by his or her approval. In this way, Bowles rejected Gilded Age critics' faith not only in the efficacy of institution building, but in the public's ability to shape and mould the future of American art.

Bowles's promotion of a decontextualized moment of revelation as the model for reception thus sharply limited art's audience. It also significantly narrowed the parameters of audience participation in the process of artistic production. Bowles's representation of audiences per se confined their activity within the narrow boundaries of passive "reception" or "observation." Mere receptacles for art that "happened," Bowles's observers' only choice lay in the decision to approach art with an "open mind" or one sealed shut by art-world prejudice. Of his own biases, he wrote that 
I am indifferent as to whether photography goes up or down, being a fatalist as to the progress of the arts, and believing with Whistler that art happens, that it depends entirely upon the individual worker, and that we can do little to either accelerate or retard its progress[.] $(1907,17)$

Judgment, then, lay in the observer's ability to discern the unfolding of a mysterious process about which he probably knew almost nothing. In this way, Bowles recast looking as an almost wholly passive act, in which observers' choices played no role in the future of American artistic production.

Camera Work's redefinition of the artistic "public" marked the final undoing of the autonomous audience championed by amateur critics in the Gilded Age. No longer the foot soldiers of an imminent revolution in which audiences determined the outcome of America's artistic future, viewers became simple observers of events beyond their control or influence. While promoting a new art, Stieglitz dismantled the machine that made art go. When the dust cleared, all that remained was a sleek, well-honed column of artists, marching towards the future. As inaudible observers, hangers-on to the campaign for art had little more effect than the throngs that had crowded the edges of battle during the nation's recent civil war.

Camera Work's transformation of nearly all commentary to fit a single, coherent narrative about the Photo-Secession and artistic photography marked both the journal's centrality in the creation of a photographic avantgarde and its departure from previous criticism. In orchestrating the establishment of a complex institutional and discursive context for the reception of Secessionist productions, Alfred Stieglitz ensured their success and the success of an emerging modernist photographic aesthetic. By erasing the influence of his institution-building predecessors and constructing Secessionist works as inevitable, natural, and independent of institutional entanglement, he laid the groundwork for a modernist sensibility increasingly hostile to the needs, desires, and aspirations of the public. 


\section{Endnotes}

1. As Orvell argues,

Beginning around the turn of the century a new approach to the camera evolved, initiated in the work of Alfred Stieglitz, whose influence on the vocabulary of photography was profound over the next several decades. This approach emphasized the photographer's eye, his particular angle on the subject, whether detailed close-up or aerial view; it emphasized the idiosyncrasy of the camera's way of seeing as a function of its mechanical character, rather than its capacity to reproduce a facsimile of 'normal' vision. For the authenticity of the camera, it was believed, was the authenticity of a machine that was accepted as a machine. And the photograph functioned not as a surrogate for experience, or as a memory device, but as an instrument of revelation, changing our way of thinking about, and seeing the world. $\quad(1989,198-99$, emphasis added)

Haines succinctly describes this as "Stieglitz's success in making truth visible" $(1982,5)$.

2. There is some disagreement among scholars as to the exact trajectory of American artistic photography in the early decades of the twentieth century. While some authors see Stieglitz's prewar efforts in terms of an antiquated pictorialist style which drew derivatively on the conventions and vision of painting, and others argue that Stieglitz began to see the apprehension and depiction of stripped-down objects as the photographic route to spiritual understanding at a much earlier date, some authors take the position that there was not a sharp break between the painterly pictorialist style of the turn of the century and the hardedged style which developed in the ensuing decades. Camera Work itself is a record of this lengthy transition from the atmospheric to the concrete. See Arrowsmith and West (1992); Dijkstra (1969, 95-107); Green (1973, "Introduction"); Orvell (1989, chs. 3 and 6); Bunnell (1993, 8-12).

3. The image of Stieglitz as photographic seer and father of modernism was one which he himself cultivated, and which his contemporaries were unafraid to promote. In a 1934 volume whose contributors included William Carlos Williams, Marsden Hartley, and Gertrude Stein, Harold Clurman wrote that the photographer's

capacity for love has made Stieglitz a seer. Because nothing is too unimportant for him to see, and because everything he sees finally becomes the object of an allembracing and therefore single love, his very simple, always accessible photographs take on a 'mystic' quality, and Stieglitz is regarded as a 'visionary'! We are unused to such attention in modern times. Stieglitz is incessantly attentive. He is attentive to everything that immediately confronts him. Because he cares for everything, because he loves[.] (quoted in Frank et. al [1934, 268]

See also Dorothy Norman's aptly titled Alfred Stieglitz: Introduction to an American Seer (1960).

4. For the most concise expression of the need to reevaluate cultural production in terms of the conditions of practice, as opposed to text- or object-based analysis, see Williams ([1973] 1980). 
5. Much of the literature on Stieglitz is devoted to describing Stieglitz's "good works" within the art world, including his role in the Photo-Secession, Camera Work, and the Little Gallertes. By and large, however, this literature concerns itself with these institutions only as inert vessels for the presentation of a deracinated aesthetic "message." Peninah Petruck, thus, describes Stieglitz's "passion for innovation and experimentation" as "that of a missionary," locatıng Camera Work and the Little Galleries as the prime outlets for his zeal $(1981,25)$. In describing the actual impact of these two institutions, however, Petruck merely describes them as venues in which Stieglitz elaborated his ideas or presented previously unknown European modernists to an American audience, without exploring the character of the institutions themselves. On the whole, scholarly descriptions of Stieglitz's projects rely heavily on his own depiction of them as "laboratories," or disinterested spaces for unfettered "experimentation"-terms which themselves drew on the cultural authority and supposed neutrality of science. Matthew Baigell, for instance, writes that "Stieglitz in his various galleries ... offered something equivalent to Emerson's Concord - a place in which ideals could be considered reasonably free of trade and commerce" (1987). To date, the relationship between modernist criticism as discourse and modernist criticism as institution has not been explored in a full and convincing manner.

6. The most thorough examination of this dynamic can be found in the work of Keller (1984), who argues that the success of "Art Photography" owed more to Stieglitz's promotional efforts than to the content of his work or the work of his associates. Although his argument is highly suggestive, Keller's central preoccupation with the epistemological ramifications of Stieglitz's institution-building activities renders it ultimately unsatisfying. To Keller, Stieglitz's organizational activities are problematic mainly in that they led to the creation of "a prestigeoriented pseudo art world" whose components failed to live up to the standards set by "legitimate and functional support institutions" such as the academy, and which promoted mediocre work as "genuinely innovative." The problem with this line of analysis is that it presumes that the evaluation of art works can ever take place outside of "the manufacture of ... fame," and that by erasing the "promotional" effects of Stieglitz's organizational activities we can achieve an objective "re-evaluation of the movement."

7. Alan Trachtenberg's (1989, ch. 4) account of contemporaries' reception of the work of Lewis Hine provides stunning evidence of Stieglitz's narrowing affect on American definitions of "artistic" photography. According to Trachtenberg, Stieglitz initiated and codified a deep and artificial gulf in American consciousness between "artistic" photographs, made by selfconsciously artistic producers and judged solely according to aesthetic qualities, and "documentary" photographs, which neither bore the stamp of artistic intent nor excluded accidental detail. This gulf, Trachtenberg argues, prevented contemporaries from recognizing Hine's socially-motivated work as "art" at all. Trachtenberg further interprets Stieglitz's drive for accommodation within the established structures of the art world as a backward-looking, anti-avant-garde strategy, however. In contrast, I will argue that the drive for official recognition is itself integral to the American avant-garde.

8. A fascinating and unusual attempt to relate organizational transformations in the corporate and the cultural sphere, and to examine their effect on modernist production, can be found in Smith (1993).

9 A source of seemingly endless fascination for scholars, the avant-garde inspires a continuously growing body of literature. The bulk of this scholarship concerns itself, however, with a limited set of questions, and is particularly interested in fine-runing an already overworked theory or definition of the "avant-garde." Generally sceptical about the claims of historical avant-gardes-or the possibulity for a "true" avant-garde to have existed under any crr- 
cumstances-this literature, although historicizing, has done little to examine the practices of concrete historical avant-gardes. Thus, various authors have unearthed, in labourious detail, the historical unfolding of the metaphor of the avant-garde, the logic entailed in this constantly shifting discourse, and the impact of them both on the formal character of the artistic and literary productions of the late-nineteenth and twentieth centuries. Describing their activity as a search for a new aesthetic language, untrammelled by traditions, Matei Calinescu ([1977] 1987) writes that the primary objective of the avant-garde "was to overthrow all the binding formal traditions of art and to enjoy the exhilarating freedom of exploring completely new, previously forbidden, horizons of creativity. For they believed that to revolutionize art was the same as to revolutionize life" (112). Considerably less attention has been directed towards providing an account of the character of specific historical avant-gardes as social and organizational entities. While the language of the avant-garde, rooted in military and revolutionary metaphor, is itself rich with organizational implications, most scholars have glossed over the organizational activity central, first, to the creation of avant-gardes as conglomerations of sympathetic producers, and, second, to the promotion, dissemination, and reception of their works. Poggioli ([1962] 1971) set the stage for this framework in his classic study, by describing the "little magazine" as the solitary voice of the avant-garde, crying alone against the clamour of "mass journalism" and the uniformity of the dominant culture. In describing the avant-garde journal as the bearer of fully formed aesthetic positions or works, Poggioli ignored the messenger completely in favour of the message carried, writing that

sometimes the goal of the little review is merely to publish proclamations or a series of manifestos, announcing the foundation of a new movement, explicating and elaborating its doctrine, categorically and polemically. Or else they merely present to a friendly or hostile public an anthology of the collective work in a new tendency or by a new group of artists and writers. (22)

Although an overt response to Poggioli, Bürger's (1984) approach replicates this deracinated account of the avant-garde and its productions, relying on a notion of "self-criticism" to describe its moment of origin. Bürger writes,

with the historical avant-garde movements, the social subsystem that is art enters the stage of self-criticism. Dadaism, the most radical movement within the European avant-garde, no longer criticizes schools that preceded it, but criticizes art as an institution, and the course its development took in bourgeois society....

Only after art, in nineteenth-century Aestheticism, has altogether detached itself from the praxis of life can the aesthetic develop 'purely.' (22)

In Bürger's theory, thus, the avant-garde's only concrete spur to self-criticism is not social conditions, but art itself. A similar tendency can also be seen in Abrahams (1986). See also Egbert (1967).

10. Works exhibited by Photo-Secession member George A. Seeley, for example, provoked the editor to comment that

although it was a severe test for these pictures to be hung after the exceptionally imaginative [drawings] of Miss [Pamela Colman] Smith, they well sustained the 
prestige of the galleries. The exhibition is still open as we go to press.

("Photo-Secession Notes," Camera Work 18 [April 1907], 49)

This self-conscious tone of reassurance quickly gave way, however. By October, the editors had adopted a more matter-of-fact strategy for demonstrating the appropriateness of displaying photography alongside works in more traditional media, breezily mentioning photography, etching, and drawing all in the same breath as if there had never been any dispute as to photography's position among the arts.

Some of the exhibitions planned for the succeeding month are: Drawings by Rodin; Etchings by Willi Geiger, of Munich; Photographs, by Frank Eugene; by Eduard Steichen, in color and monochrome; by Joseph T. Keiley; by F. Holland Day; a series of platinotype studies made by Clarence $\mathrm{H}$. White and Alfred Stieglitz in collaboration [etc.].

("Exhibitions at the Little Galleries," Camera Work 20 [October 1907], 26)

11 As the editors wrote of the first nonphotographic exhibition in 1907,

The exhibition of drawings in black and color by Miss Pamela Colman Smith, held at the Little Galleries of the Photo-Secession in January, marked, not a departure from the intentions of the Photo-Secession, but a welcome opportunity of their manifesting. The Secessionist Idea is neither the servant nor the product of a medium. ("The Editors' Page," Camera Work 18 [April 1907], 37-38)

12. "'Camera Work' owes allegiance to no organization or clique, and though it is the mouthpiece of the Photo-Secession that fact will not be allowed to hamper its independence in the slightest degree" ("An Apology," Camera Work 1 [January 1903], 16).

13. Indeed, the editors suggested that Camera Work constituted their readers' exclusive source of information about photography, writing that "we know that of our readers but a small percentage see any other publication devoted to pictorial photography except Camera Work" ("The Editors' Page," Camera Work 18 [April 1907], 37-38).

14. The editors occasionally noted this generally unspoken circumstance, reprinting the catalogue from the 1908 exhibition of Rodin drawings, for example, explicitly "for the benefit of the readers of Camera Work who did not have the pleasure of seeing the exhibition" ("The Rodin Drawings at the Photo-Secession Galleries," Camera Work 22 [April 1908], 35-41).

15. On the relationships between Stieglitz and various participants in his ventures, see Lowe (1983).

16. Charles Caffin (1854-1918), who emigrated from Britain in 1892, was one of the foremost critical defenders of artistic photography in the United States. After doing decorative work at the World's Columbian Exhibition in Chicago, Caffin moved to New York, where he worked as a critic for Harper's Weekly, the Evening Post, the New York Sun, the Studio, and the New York American, as well as lecturing at the Pennsylvania Academy of Fine Arts and the Yale School of Fine Arts. Although initially hostile to Stieglitz's work, Caffin was convinced of its merit after Stieglitz recommended him to the editor of Everybody's to author a series of articles the editor had asked Stieglitz to write. Thereafter, Caffin became committed to demonstrating the artistic merits of photography, both in articles and in his Photography as a Fine Art (1901). On Caffin, see Underwood (1983); Wilson and Fiske (1888, 22:261). 
17. The editors' firmness on this point is evidenced by their reiteration, in the next issue, that "Mr. Strauss did not represent the spirit or ideas of those 'photographic pictorialists' who have gained the recognition of modern photography in the field of art" ("Exhibition Notes-Re St. Louis," Camera Work 2 [April 1903], 51). The friction between artistically minded photographers and their commercial/professional associates was not limited to Stieglitz's circle, but was a mainstay of organized amateur photographic "reform" rhetoric during the last two decades of the nineteenth century. For an account of amateurs' attempts to differentiate themselves from commercial photography, see Keller $(1984,251-52)$.

18. In distinguishing themselves from profit-making photographers, Secessionists modelled themselves after German secession movements, which were established partly as a reaction against the commercialization of the Academy. On those movements, see Karl $(1985,109$ 110).

19. By the time he founded the Photo-Secession, Stieglitz had already honed his skills as art-world organizer. Under his stewardship, and due in particular to his management of Camera Notes, New York's Camera Club had enjoyed its greatest period of success. Perceiving his PhotoSecession activities as treasonous, the club later revoked his membership. See Strauss (1908, 26).

20. The most notorious example of this process of rebellion and decadence was, of course, the National Academy of Design (1826), which had been founded by rebel New York artists disgruntled with the American Academy of Fine Arts' control by merchants and other nonartists. See Bender (1987, 126-30); Harris ([1966] 1982, 96-99).

21. There were several precedents for this kind of "sympathetic" association in Europe, including the Pre-Raphaelite Brotherhood and the Linked Ring, to which Stieglitz was himself elected. In the United States, however, such associations were almost unknown, with the exception of the short-lived Society for the Advancement of Truth in Art at mid-century.

22. Current literature reproduces this interpretation, emphasizing the "collective faith" that held Secessionists together. See Watson $(1991,68)$.

23. On European Secession movements' self-conscious withdrawal from the market, see Karl (1985, 109-110). On Stieglitz and corporate sponsorship, see Kiefer (1992).

24. Keiley also took a personal interest in photography's re-admission into Philadelphia's official art scene; he had been a participant in the first Philadelphia Photographic Salon of 1898 and experienced its subsequent lockout (Peterson 1993, 169).

25. Keiley's spin on this event was not unique within Camera Work. In describing the change from "ridicule to silence and ... amusement to conviction" that the exhibitions at the Little Galleries had wrought during their first year, the editors wrote that

it comes as a peculiarly gratifying climax to our endeavors that the Pennsylvania Academy of the Fine Arts, one of the foremost and most influential of the American art institutions, has, unasked, requested us to select and hang an exhibition of photographs on its walls".

("Photo-Secession Notes," Camera Work 15 [July 1905], 42, emphasis added).

26. Cheerfully setting the terms of selection for the 1910 photographic exhibition at the Buffalo Fine Arts Academy (Albright Art Gallery), however, the Secession seemed to have no trouble assessing the works of others, announcing in Camera Work that

those desirous of exhibiting in the ... Open Section are requested to send their prints, unframed, express prepaid, to 291 Fifth Avenue, New York City, where 
they will be judged by The Photo-Secession.... The selection will be governed by the principle of Independent Vision and Quality of Rendering. To eliminate accidental successes, each exhibitor in this section must be represented by at least three examples."

("An Important International Exhibition of Photographs," Camera Work 30 [April 1910], 60)

27. "We are devotedly thankful that there are fewer photographic 'Art Exhibitions' now than there were several years ago. What has been lost in quantity, however, has been gained in quality. (We wish the same could be said of the 'real' art exhibitions.)" (Edirors 1910, 53).

28. The editors also used this line of argument in describing the Photo-Secession, writing that "the aim of the Photo-Secession is loosely to hold together those Americans devoted to pictorial photography in their endeavor to compel its recognition, not as a handmaiden of art, but as a distinctive medium of individual expression." By highlighting the looseness of its organization and portraying its attempt to build audiences as the search for "recognition," Camera Work deflected attention away from the Secession's organizational efforts and towards its artistic productions ("The Photo-Secession," Camera Work 6 [April 1904], 53, emphasis added).

29. The editors took pains to remind readers that the Little Galleries had nothing in common with art institutions with which they might be familiar, urging potential visitors to "[remember] that the Little Gallery is nothing more than a laboratory, and experimental station, and must not be looked upon as an Art Gallery in the ordinary sense of that term." "Photo-Secession Notes," Camera Work 30 (April 1910), 47. See also Haviland (1912a, 36), who described shows at 291 as "demonstrations of development, rather than either exhibitions of final accomplishment of 'shows' in the popular sense.

30. As Haviland wrote, "If the position of photography among the arts is to be firmly and permanently established, this can be accomplished by proving it capable of standing the test of comparison with the best work in other media and not by isolating it" $(1910,42)$.

31. In the United States, William Merritt Chase engaged in similar activiry within his own studio, which was widely known for its meticulously crafted display. Chase's fondness for orientalist gewgaws and crowded presentation marked his sympathy, however, with certain aspects of nineteenth-century modes of exhibition, if not with their political ramifications. On Chase, see Bryant (1991).

32. An excellent discussion of Whistler's activities in exhibition design can be found in Bendix (1995, 205-268).

33. A goal that Stieglitz's rival impresario Robert Henri had been unable to accomplish. As James Gibbons Huneker colourfully exclaimed,

'No, messieurs et mesdemoiselles, les Independents, you'll never beat the Academy at its own stupid game by substituting quantity for quality! Two wrongs don't make a right. Oppose quality to quantity. Slash off the heads of two-thirds of your applicants and try to kill the demon of vain display.'

(Huneker, "The Younger American Painters' and the Press," New York Sun, reprinted in Camera Work 31 [July 1910], 51)

34. Caffin used a similar line of argument in describing the (Secession-juried) photographic exhibition at Buffalo of 1910 , writing that "One received a suggestion that the exhibition represented not an incident, but for the time being the purpose of the building's existence" $(1911,21)$. 
35. Camera Work also frequently served as a surrogate display venue for non-Secessionist exhibitions at the Little Galleries; for example, several drawings "From the Drawings Exhibited at the Rodin Exhibition[,] Photo-Secession Gallery, January, 1908; April, 1910" were later reproduced in a series of plates in the journal. Plates I-VI; I-II, Camera Work 34-35, 36 (April-July, October, 1911).

36. Defending the Little Galleries' increasingly frequent turn to nonphotographic exhibitions, Haviland suggested that display in Camera Work served as a more than adequate surrogate for live exhibition. "The season, which ended with but a single photographic exhibition, has led many of our friends to presume that the Photo-Secession was losing its interest in photography and the 'The Bunch at 291 ' was steering the association away from its original purpose. The best answer is to be found in the pages of Camera Work,-the official organ of the PhotoSecession-in which the best examples of photography are presented regularly to its subscribers" (Haviland 1910, 42).

37. According to Trachtenberg, Stieglitz frequently recontextualized his own work, providing historical re-interpretations of his early New York photographs decades after their makıng (1989, ch. 4).

38. Editors 1903a, 26-27; "Exhibition Notes-The Photo-Secession," Camera Work 10 (April 1905), 49-50; "American Photography and the Foreign Annuals," Camera Work 14 (April 1906), 63.

39. While this list generally contained museums, galleries, and camera clubs, it also included "General di Cesnola, the Director of the Metropolitan Museum of Art" and "His Majesty the King of Italy," who had given the Secession a "special award" (Editors 1903c, 60-61; "The Photo-Secession," Camera Work 9 [January 1905], 56-57; "Foreign Exhibitions and the Photo-Secession-Notes," Camera Work 7 (July 1904], 39-40).

40. The most notable examples of this were Britain's Linked Ring and the infamous Salon des Refusés. Editors 1903a, 26-27; "Exhibition Notes," Camera Work 12 (October 1905), 59, "Calendar of Exhibitions," Camera Work 14 (April 1906), advertising section.

41. "The trouble with most . . artists is that they have 'too much ego in their cosmos.' While the majority of men are content to subordinate their ego to the aggregate cosmos, and those whose ego is of superior usefulness or superior audacity reap a material benefit, the artist is not measuring his ego with the world, but hugging it to himself. It is so dear to him that he cherishes it in seclusion, and gives out little scraps of it in charity to the world. This he calls expressing himself; and when the world, full of large preoccupation and in no need of charity, overlooks his scraps, he gives it bad names" (Caffin 1905, 25-26; see also Caffin 1907b).

42. Reviews of Secession exhibitions frequently contained excerpts from their catalogues; on occasion, these reprinted catalogues consisted not merely of positive assessments by the exhibition's organizers, but comments by the artists themselves. In defending an exhibition of watercolours by Gelett Burgess that had been accused of being insufficiently shocking, Paul Haviland allowed "Mr. Burgess [to] explain his own aim, and to that end reprint his introduction to the catalogue of his water-colors, "Essays in Subjective Symbolism" (1912b, 46-47).

43. "The Rodin Drawings at the Photo-Secession Galleries," Camera Work 22 (April, 1908), 35-41. See also "Photo-Secession Exhibitions," Camera Work 29 (January 1910), 51-54.

44. McCormick, "in the Press," quoted in "The Rodin Drawings at the Photo-Secession Galleries," Camera Work 22 (April, 1908), 39.

45. J. N. Laurvik, "in the Times," quoted in "The Rodin Drawings at the Photo-Secession Galleries," Camera Work 22 (April, 1908), 36. 
46. J. E. Chamberlin "in the Evening Mail," Arthur Hoeber "in the Globe," quoted in "The Rodin Drawings at the Photo-Secession Galleries," Camera Work 22 (April, 1908), 37, 39.

47. Caffin's insufficient defence of "straight" photography met the following response:

We are glad to print the article which appears in this number from the pen of Mr. Caffin, the art critic, giving his impressions of these studies. We have no intention of commenting in any way upon Mr. Caffin's views, but feel that it may be interesting, in passing, to supplement an incomplete statement made by him of $\mathrm{Mr}$. Herzog's method of achieving some of his results. Mr. Caffin alludes to Mr. Herzog's composite groups, but omits to mention his actual method of producing, let us say, The Banks of Lethe, assuming that he posed the group of figures as rendered in that composition and then photographed it. As a matter of fact $\mathrm{Mr}$. Herzog proceeded approximately as follows: having made innumerable single- or occasionally double-figure studies on $4 \times 5$ plates, and having made bromide enlargements from each of these negatives, and having from these enlargements cut out the figures, paper-doll fashion, he then proceeded, on a large panel, and with these figures and a paper of pins, to group and re-group, arrange and rearrange-in short, carry on experiments in his 'hunt for the line!' When finally the composition satisfied his eye, he pasted down the pinned figures and with brush and pigment filled the gaps and pulled together the sections of his composition. Lastly, he photographed this result in various sizes, thus producing a number of 'original' negatives. From one of these the accompanying photogravure was made without any tool work or retouching whatever.

(“Our Articles," Camera Work 17 [January 1907], 41)

This response was to Caffin (1907c).

48. Recent literature tends to reiterate this, representing Stieglitz's influence as immediate, spellbinding, contextless, and driven purely by his artistic productions. Haines, for example, writes that "Stieglitz's major contribution to writers was in providing contacts" not with other writers, but with "avant-garde aesthetics" $(1982,7)$.

49. The latter assumption is so deeply rooted in our thinking about art, indeed, that a writer as sensitive as Daniel Herwitz, in attempting to develop a contemporary account of the avantgarde which escapes the grip of avant-garde self-interpretation, exclaims that "sometimes a painting is just a painting" $(1993,3)$.

50. Camera Work's attacks on the public sometimes took a rather lugubrious turn, with one unnamed author crying,

why is a man who fights for an ideal of humanity, no matter whether a poet, reformer, philosopher or artist, always hooted by the crowd, and pelted with mud, even by his friends! It can not be otherwise. ... The public has no time to reflect. It is only concerned with the effect. Its esthetic appreciation lives on memories or reminiscences. It admires only what it has seen before. It is always opposed to real originality. The road of novel ideas is too rough for them. Discrimination is not granted to the Philistines."

("The Fight for Recognition," Camera Work 30 [April 1910] 22-23) 
51. Critic and playwright C. Sadakichi Hartmann (1867-1944) began his critical career in Boston writing for the Advertiser and the Boston Transcript. Enlisting the support of art-world figures such as artists Albert Bierstadt, W. M. Chase, Augustus St. Gaudens, Robert Henri, and curator and collector Ernest Fenellosa, Hartmann founded his own journal, The Art Critic, in 1893, but was forced into bankruptcy the same year after being arrested and tried for the publication of his play Christ. Hartmann's eccentric behavior and antagonistic style hindered his career as a writer, but were overlooked by Stieglitz, who tolerated his friend's pricklier aspects and who cited Hartmann as an essential aesthetic influence at the turn of the century. Hartmann's tenure at Camera Work is generally regarded as the most important period of his criticism, and is also the time during which he had the most art-world influence, especially among photographic circles. On Hartmann, see Weaver (1991, 1-44).

52. "As Mr. Stieglitz has asked me to write 'at any length and on any subject,' I am enabled at last to sit down and analyze my photographic emotions" (Bowles 1907, 17).

\section{Works Cited}

Abrahams, Edward. 1986. The Lyrical Left: Randolph Bourne, Alfred Stie glitz, and the Origins of Cultural Radicalism in America. Charlottesville: University Press of Virginia.

Arrowsmith, Alexandra and Thomas West (eds.) 1992. Two Lives: A Conversation in Paintings and Photographs. New York: HarperCollins.

Baigell, Matthew. 1987. "American Landscape Painting and National Identity: The Stieglitz Circle and Emerson," Art Criticism 4 (1): 27-47.

Bender, Thomas. 1987. New York Intellect A History of Intellectual Life in New York City, from 1750 to the Beginnings of Our Own Time. New York: Knopf.

Bendix, Deanna Marohn. 1995. Diabolical Designs: Paintings, Interiors, and Exbibitions of James McNeill Whistler. Washington: Smithsonian Institution Press.

Bowles, J. M. 1907. “Photography, what D'Ye Lack?” Camera Work 19 (July): 17-20.

Bryant, Jr., Keith L. 1991. William Merritt Chase, A Genteel Bohemian. Columbia, MO: University of Missouri Press.

Bunnell, Peter C. 1993. Degrees of Guidance: Essays in Twentieth-Century American Photography. Cambridge and New York: Cambridge University Press.

Bürger, Peter. 1984. Theory of the Avant-Garde. Translated by Michael Shaw. Minneapolis: University of Minnesota Press.

Caffin, Charles H. 1903. "Pictorial Photography: The St. Louis Exposition," Camera Work 1 (January): $42-45$.

. 1905. "As Others See Us," Camera Work 10 (April): 25-27.

. 1906. "The Recent Exhibitions-Some Impressions," Camera Work 16 (October): 33-37

1907a. "Tweedledum and Tweedledee," Camera Work 19 (July): 26-27.

1907b. "Emotional Art: After Reading the 'Craftsman'," Camera Work 20 (October): 32-34.

1907c. "Is Herzog Also Among the Prophets?" Camera Work 17 (January): 17-23.

1911. "The Exhibition at Buffalo," Camera Work 33 (January): 21-23.

Calinescu, Matei. [1977] 1987. Five Faces of Modernity: Modernism, Avant-Garde, Decadence, Kitsch, Postmodernism. Durham, NC: Duke University Press.

Crunden, Robert. 1982. Ministers of Reform: The Progressives' Achievement in American Civilization, 1889-1920. New York: Basic Books.

Djkstra, Bram. 1969. The Hieroglyphics of a New Speech: Cubism, Stieglitz, and the Early Poetry of William Carlos Williams. Princeton, NJ: Princeton University Press.

Editors, The. 1903a."America at the London Salon," Camera Work 1 (January): 26-27. 
. 1903b. "Exhibition Notes-Photo-Secession Notes," Camera Work 2 (April): 50-51. 1903c. "Photography at Important Art Exhibitions," Camera Work 1 (January): 60-61. 1910. "A Daniel Come to Judgment," Camera Work 31 (July): 52-54.

Egbert, Donald D. 1967. "The Idea of 'Avant-Garde' in Art and Politics," American Historical Review 73 (December): 339-66.

Ferber, Linda S. and William H. Gerdts (eds.) 1985. The New Path: Ruskin and the American PreRaphaelites. New York: Schocken Books and the Brooklyn Museum.

Fitzgerald, Charles. [1905] 1906. "The Pictorial Photographers," New York Evening Sun, (December 9). Reprinted in "The Photo-Secession Galleries and the Press," Camera Work 14 (April 1906).

Frank, Waldo, et. al. 1934. America \& Alfred Stieglitz: A Collective Portrait. Garden City, NY: Doubleday, Doran and Company.

Gerdts, William H. et. al. 1990. Ten American Painters. New York: Spanierman Gallery.

Green, Jonathan. 1973. Camera Work: A Critical Anthology. Millerton, NY: Aperture.

Haines, Robert. 1982. The Inner Eye of Alfred Stieglitz. Washington, DC: University Press of America.

Harris, Neil. [1966] 1982. The Artist in American Society: The Formative Years, 1790-1860. Chicago:University of Chicago Press.

Hartmann, C. Sadakichi. 1904. "The Photo-Secession Exhibition at the Carnegie Art Galleries, Pittsburg [sic], Pa.," Camera Work 6 (April): 47-51.

1910. "That Toulouse-Lautrec Print!," Camera Work 29 (January): 36-38.

. 1912. "The Esthetic Significance of the Motion Picture," Camera Work 38 (April): 19-21.

Haviland, Paul B. 1909. "The Home of the Golden Disk," Camera Work 25 (January): 21-22. 1910. "Photo-Secession Notes," Camera Work 31 (July): 41-42.

—. 1912a. "Photo-Secession Notes," Camera Work 38 (April): 36-37. 1912b. "Notes on the Exhibitions at '291'," Camera Work 37 (January): 46-47.

Herwitz, Daniel. 1993. Making Theory/Constructing Art: On the Authority of the Avant-Garde. Chicago and London: University of Chicago Press.

Homer, William Hines. 1983. Alfred Stieglitz and the Photo-Secession. Boston: Little, Brown. 1977. Alfred Stieglitz and the American Avant-Garde. Boston: New York Graphic Society.

Horowitz, Helen Lefkowitz. 1976. Culture and the City: Cultural Philanthropy in Chicago from the 1880s to 1917. Lexington, KY: The University Press of Kentucky.

Karl, Frederick R. 1985. Modern and Modernism: The Sovereignty of the Artist, 1885-1925. New York: Atheneum.

Keiley, Joseph T. 1906. "The Photo-Secession Exhibition at the Pennsylvania Academy of Fine ArtsIts Place and Significance in the Progress of Pictorial Photography," Camera Work 16 (October): 45-51. 1911. "The Buffalo Exhibition," Camera Work 33 (January): 23-29.

Keller, Ulrich F. 1984. "The Myth of Art Photography: A Sociological Analysis," History of Photography 4 (October-December): 249-275.

Kiefer, Geraldine Wojno. 1992. "Alfred Stieglitz, Camera Work, and Cultural Radicalism," Art Criticism 7 (2): 1-20.

Lowe, Sue Davidson. 1983. Stieglitz: A Memoir/Biography. New York: Farrar, Strauss and Giroux. Miller, Lillian B. 1966. Patrons and Patriotism: The Encouragement of the Fine Arts in the United States. Chicago: University of Chicago Press.

Morgan, H. Wayne. 1978. New Muses: Art in American Culture, 1865-1920. Norman, OK: University of Oklahoma Press. 
Canadian Review of American Studies Revue canadienne d'études américaines

Naef, Weston J. 1978.The Collection of Alfred Stieglitz: Fifty Pioneers of Modern Photography. New York: Metropolitan Museum of Art/Viking.

Norman, Dorothy. 1960. Alfred Stieglitz: Introduction to an American Seer. New York: Duell, Sloan \& Pearce.

Orvell, Miles. 1989. The Real Thing: Imitation and Authenticity in American Culture 1880-1940. Chapel Hill and London: University of North Carolina Press.

Peterson, Christian. 1993. Alfred Stieglitz's 'Camera Notes.' New York: W. W. Norton \& Co./The Minneapolis Institute of Arts.

Petruck, Peninah R. Y. 1981. American Art Criticism, 1910-1939. New York and London:Garland. Poggioli, Renato. [1962] 1971. The Theory of the Avant-Garde. Translated by Gerald Fitzgerald. New York: Icon Editions.

Smith, Terry. 1993. Making the Modern: Industry, Art, and Design in America. Chicago and London: University of Chicago Press.

Stieglitz, Alfred. 1905."'The 'First American Salon at New York'," Camera Work 9: (January): 50-51.

Strauss, John Francis. 1908. "Mr. Stieglitz's 'Expulsion'-A Statement," Camera Work 22 (April): 26.

Trachtenberg, Alan. 1989. Reading American Photographs: Images as History, Mathew Brady to Walker Evans. New York: Hill and Wang.

Underwood, Sandra Lee. 1983. Charles Caffin: A Voice for Modernism, 1897-1918. Ann Arbor: U.M.I. Press.

Watson, Steven. 1991. Strange Bedfellows: The First American Avant-Garde. New York: Abbeville Press.

Watson-Schutze, Eva. 1903. "Salon Juries," Camera Work 2 (April): 46-47.

Weaver, Jane Calhoun (ed.) 1991. Sadakichi Harimann: Critical Modernist. Berkeley and Los Angeles: University of California Press.

Willard, S.L. 1903. "Exhibition Notes-The Third Salon in Chicago," Camera Work 2 (April):49-50.

Williams, Raymond. [1973] 1980. Problems in Materialism and Culture: Selected Essays. London: Verso.

Wilson, James Grant and John Fiske (eds.) 1888. Appleton's Cyclopedia of American Biography, Volume 1. New York: D. Appleton \& Co.

Zilczer, Judith. 1985. "Alfred Stieglitz and John Quinn: Allies in the American Avant-Garde," American Art Journal 17 (Summer): 18-33.

\section{Journal Articles Cited by Title}

"American Photography and the Foreign Annuals," Camera Work 14 (April 1906): 63.

"An Apology," Camera Work 1 (January 1903): 15-16.

"Calendar of Exhibitions," Camera Work 14 (April 1906): advertising section.

"The Editors' Page," Camera Work 18 (April 1907): 37-38.

"Exhibition Notes--Re St. Louis," Camera Work 2 (April 1903): 51.

"Exhibition Notes-The Photo-Secession," Camera Work 10 (April 1905): 49-50.

"Exhibition Notes," Camera Work 11 (July 1905): 57.

"Exhibition Notes," Camera Work 12 (October 1905): 59.

"Exhibitions at the Little Galleries," Camera Work 20 (October 1907): 26.

"The Fight for Recognition," Camera Work 30 (April 1910): 21-23.

"Foreign Exhibitions and the Photo-Secession-Notes," Camera Work 7 (July 1904): 39-40. 
"An Important International Exhibition of Photographs," Camera Work 30 (Apri] 1910): 60.

"Our Articles," Camera Work 17 (January 1907): 41.

"The Photo-Secession," Camera Work 3 (July 1903): supplement.

"The Photo-Secession," Camera Work 6 (April 1904): 53.

"The Photo-Secession," Camera Work 9 (January 1905): 56-57.

"Photo-Secession Exhibitions," Camera Work 29 (January 1910): 51-54.

"The Photo-Secession Galleries and the Press," Camera Work 14 (April 1906): 33-40.

"Photo-Secession Notes-St. Louis," Camera WorkS (January 1904): 50

"Photo-Secession Notes," Camera Work 6 (April 1904): 39-40.

"Photo-Secession Notes," Camera Work 15 (July 1905): 41-42.

"Photo-Secession Notes," Camera Work 18 (April 1907): 49.

"Photo-Secession Notes," Camera Work 30 (April 1910): 47-54.

"Pictorial Photography: The St. Louis Exposition," Camera Work 1 (January 1903): 37.

"The Rodin Drawings at the Photo-Secession Galleries," Camera Work 22 (April 1908): 35-41.

"The Younger Arnerican Painters' and the Press," Camera Work 31 (July 1910): 43-51. 
